\title{
Assessment of Business Educators Competency Level in Teaching Office Application And Office Technology Segments of Office Technology And Management Courses in Selected Polytechnics in North-East Nigeria
}

\author{
Nnaji Florence Oluchi, Hauwa Bawa Pyiki
}

\begin{abstract}
The study titled Assessment of Business Educators Competency Level in Teaching Office Application and Office Technology segments of Office Technology and Management Courses in selected Polytechnics in Northeast of Nigeria was conducted to determine competency levels of office technology and management business educators. Two specific purposes, two research questions and two null hypotheses guided the study. Survey design was adopted for the study. The population of the study was 889 which comprised of 49 lecturers and 840 students. The entire population of lecturers and a sample of 262 students drawn out of 840 population of students using Taro Yamane formula constituted a sample size of 311 which was studied. A 25-item structured questionnaire on a 4 point Likert scale was used to elicit data for the study. The questionnaire was validated by two experts. Cronbach alpha reliability method was used to test the reliability of the instrument and it yielded a coefficient of 0.89 signifying that the instrument was reliable. The instrument was administered by the researchers and two research assistants, $98 \%$ of the questionnaire was properly completed and was used for the analysis. The weighted mean and standard deviation were used to answer the research questions. Independent t-test statistics was used to test the null hypotheses at 0.05 level of significance. The findings of the study revealed amongst others that business educators are very competent in teaching the two identified components of the business education courses namely, office application and office technology courses. There was significant difference between the mean responses of lecturers and students on the business educators' competency level in teaching office application courses in some selected Polytechnics in Northeast Nigeria. It was recommended amongst others that business educators should encourage students of OTM to be creative and innovative so that they will not be idle after graduation because they are trained for paid jobs and for self-reliance. The spirit of self-reliance should be inculcated into them by teaching them to make frequent use of the machines in the model office and computer laboratory because they are expected to make use of similar machines in their work place.
\end{abstract}

Index Terms- Assessment, Competency, Courses, Teaching.

Nnaji Florence Oluchi, Department of Office Technology And Management School of General Studies And Management Technology Federal Polytechnic Bali, Taraba State Nigeria

Hauwa Bawa Pyiki, Department of Office Technology And Management School of General Studies And Management Technology Federal Polytechnic Bali, Taraba State Nigeria.

\section{INTRODUCTION}

Highlight Teaching has much to do in the life of the learners. Teaching is an important term frequently used in regard to making the students who are the reason why teachers are found in schools (Nursery, Primary, Secondary and Tertiary) learn new things. These new things can be concept which may be both simple and complex new ideas, projects and so on. The term teaching has become more popularized with the advent of technology. Educators need to be technological advanced too. This means that more and more competency are demanded from business educators. Office technology and management (OTM) educators are not left out in this trend. Every business educator is expected to have vast knowledge in the profession. High level of competency is needed from those who impart knowledge to learners to enable these learners to appropriately fit into the society. Education that is needed in this contemporary $/ 21^{\text {st }}$ century is one that can assist the learner to be self-employed and to also work in the modern office which is characterized by high-tech devices. Competency is the ability to use skill or set of skills by an individual to properly perform a specific job. Osinem and Ugwuoke in Baba, Victor-Igwe, and Baba (2015) state that competency is an essential knowledge and skills obtainable in a profession and those which the professionals in the field must possess and be able to demonstrate at optimal level of acquisition and functioning. Encarta Dictionary (2009) defines competence as the ability to do something well, measured against a standard; especially ability acquired through experience or training. Business educators' competency in teaching-learning process of Office Technology and Management courses is a major contribution to effective performance of the graduates.

Sheila and Simeon (2015) stated that assessment allow educators to compare performance results across multiple classrooms, courses, schools, and/or learning experiences. Enahoro (2000) observes that assessment enable the teacher assess his lesson instruction and at the same time give information to parents on student's progress, promotion and graduation, motivation of schoolwork, guidance of learning, guidance of educational and vocational planning, guidance of personal development, reports and recommendations to 
future employers.Educational assessment always begins with educational values and standards. Igberaharha (2018) asserts that quality education can be assessed internally. Internal assessment also called self-assessment is to allow the tertiary institutions develop strategies that will help them.Business educators are those who read business education at tertiary institutions and teach business education courses in schools. Business Education is a programme of instruction that prepares students to take up their roles in enterprise as entrepreneurs and employers. Okoli, Utoware and Kaizer (2018) see business education as that aspect of education that exposes the learner to the acquisition of demonstrable skills that could be transformed into economic benefits. It acquaints students with skills, knowledge and attitudes to enable them succeed in the business world. Teaching is a process in which teachers apply a repertoire of teaching strategies to communicate and interact with students around academic content, and to support student engagement. Office Technology and Management courses are those courses offered in the polytechnics for the award of National Diploma (ND) and Higher National Diploma (HND) in Office Technology and Management. They are National Board for Technical Education (NBTE) approved courses for the programme. These are courses which any student who undertakes a study in OTM programme must be examined and certified as having met the requirements for the award of the certificate for that programme. Federal Republic of Nigeria (2004) stated that Office Technology and Management education is an aspect of vocational and technical education which demands that students must demonstrate appropriate skills. This behooves on business educators to use the right competency in teaching and learning so that the graduates of OTM will be knowledgeable and skilful.

\section{STATEMENT OF THE PROBLEM}

Challenges abound in the modern business office because of the new technology boom in the contemporary world. Buttressing on this point Anioke (2014) states that the constant change in the technology brings about change in taste and demands of the society, industries and market where graduates struggle for survival among several competitors. It is imperative that OTM educators be competent in teaching the courses in order to help the beneficiaries cope with the new technology. At present, teaching and learning is ICT driven. With this development business educators require attitudes and practices essential to strengthen OTM programme and enable graduates perform effectively in the modern business office. Business educators' competency level in teaching OTM courses are the solution to graduate unemployment.

According to Baba et al (2015) it is the expectation of the labour market that every graduate of office technology and management is equipped with the skills that will enable him to be competent, employable or self-reliant. However, it has been observed that most graduates of OTM are performing below the expectation of employers and the society. It has also been observed that most graduates of OTM are without gainful employment probably because the products of the programme are short of the necessary skills for self-reliance and national development. It is against these back drops that the researchers Assessed Business Educators Competency Level in Teaching Office Application and Office Technology segments of Office Technology and Management Courses in Selected Polytechnics in Northeast Nigeria.

\section{PURPOSE OF THE STUDY}

The general purpose of the study was the Assessment of Business Educators Competency Level in Teaching Office Application and Office Technology segments of Office Technology and Management Courses in selected Polytechnics in Northeast Nigeria.

Specifically, the study was designed to:

1. Assess business educators' competency level in teaching office application segment of Office Technology and Management courses in selected Polytechnics in Northeast Nigeria.

2. Ascertain business educators' competency level in teaching office technology segment of Office Technology and Management courses in selected Polytechnics in Northeast Nigeria.

\section{RESEARCH QUESTIONS}

The following research questions guided the study:

1. What are business educators' competency level in teaching office application segment of Office Technology and Management courses in selected Polytechnics in Northeast Nigeria?

2. What are business educators' competency level in teaching office technology segment of Office Technology and Management courses in selected Polytechnics in Northeast Nigeria?

\section{RESEARCH HYPOTHESES}

The following null hypotheses were formulated and tested at 0.05 level of significance.

1. There is no significant difference between the mean responses of lecturers and students on business educators' competency level in teaching office application segment of Office Technology and Management courses in selected Polytechnics in Northeast Nigeria.

2. There is no significant difference between the mean responses of lecturers and students on business educators' competency level in teaching office technology segment of Office Technology and Management courses in selected Polytechnics in Northeast Nigeria?

\section{REVIEW OF RELATED LITERATURE}

Theoretical Framework

Pavlov (1927) classical conditioning theory is important in teaching office application and office technology courses. Business educators need to stimulate the students to learn. It is important for business educators to know how to arouse learners' interest through things that will not frighten them. In 
teaching office application courses such as ICT, Shorthand, Word Processing, Database Management, and Desktop Publishing and so on. It is the duty of the teacher to salivate students interest by removing fear of failure in the case of shorthand where students have made-up minds that it is difficult and not possible to do. The business educator has the responsibility and competence of making the students understand that it is possible to understand it by using examples of those who have done it perfectly and by using positive reinforcement such as praises like good effort, very good, good attempt and gift such as pencil, shorthand pad, excellent commendations and so on to encourage the students into performance. Skinner's (1989) reinforcement theory also states that a response that is followed by reinforcement is strengthened and is therefore, more likely to occur again. In other words, responses that are reinforced tend to increase in frequency because a response increase is a change in behaviour. Business educators should keep on reminding themselves of what students' behaviours they want to increase and try to follow those behaviours with positive consequences. For example, when typically quiet students raise their hands to answer question or make a comment, business educators should be competent to call on them and give them whatever positive feedback they can. Business educators should have the competency to make their classes lively, interesting, and humorous, as well as informative, so that students are reinforced for coming to class in the first place.

Business education is an option of vocational and technical education that is designed to prepare students for the world of work and for self-reliance. It is a programme of study that equips the students with relevant skills for self and societal development. It is education that prepares students for the world of work and the world of business. Business education is education for and about training in business skills, competencies required for use in business offices, clerical occupations and that which gives occupational identity (Nnaji, 2014, Ehirheme, 2014, Obayi, Abuka and Okeke 2014, and Chigbuson, 2014). Globally, business education courses are aimed at equipping the individuals with knowledge, skills, vocations and attitudes needed to manage personal business as well as function effectively in the economic system (Njoku, 2015). Ayelotan and Sholagbade (2014) opine that business education is a programme of instruction which consists of many parts: the Office Education (presently known as Office Technology and Management) for effective careers and the general business education programmes that provide students with information and competencies. Shaibu, Oshiogwe and Mbaegbu (2014) state that it is the deliberate intent of teachers to inform students about economics and business concepts and skills that might be of use in later life.

Business educators are facilitators through which the students can acquire the right skill, knowledge, ability and competency to excel in the high-tech office of today. In the opinions of Elobuike (2010) and Asogwa, Uko and Omeh (2010) a business educator is one who has undergone a teacher preparatory programme and charged with the responsibility of managing the learning behaviour of the students. Asogwa et al maintained that a business educator is a curriculum implementer, motivator of learning activities, facilitator of learning and a guide for learning. A business educator therefore, is a professionally trained educator of business courses who is competent in teaching all the components of business courses (Ekpenyong, 2010, Babat and Madaki, 2011). Office Technology and Management (OTM) is the new nomenclature of Secretarial Studies. This change of name was necessitated by technological development. According to National Board for Technical Education (2004) secretarial studies programme must not be left out in the technological movement. In support of this view Ovbiagele and Mgbonyebi (2018) assert that the present OTM curriculum has been described as having apparent merits because of UNESCO assistance during their view which introduced an international perspective in the curricula and enable the recipients to benefit from some of the best practices around the world. According to Ademiluyi and Okwuanaso (2013) the name "Office Technology and Management" is a recent innovation which signals secretarial profession's evolution not only from an analogue era to a digital age, but also from its time-honored appendage (assistant) status to an executive/managerial one. Oborah (2011) says that the new name was approved in 2004 by the supervising body for polytechnics in Nigeria in order to keep pace with the recent global developments in Information and Communication Technology (ICT) with its attendant influence in the labour market. Nnaji and Ibe (2014) observed that OTM is designed to develop skills, abilities, understanding, attitudes, work habits and appreciation encompassing knowledge and information needed by individuals to enter and progress in employment (public or self-employment) on a useful and productive basis. Okoye and Umezuluike (2014) state that students with knowledge and skills that will enable them find a job after schooling across territorial boundaries or which they can use to create their own employment are the emphasis of the $21^{\text {st }}$ century learning.

Teaching is science as well as art. Teaching is the teacher behaviour, or activities designed and performed to produce a change in students (learners) behaviour. In a formal sense, it is the organized work adults do in the school system in their conscious effort to help the learner in their care to acquire all desirable knowledge and skills, habits and values in an atmosphere of mutual freedom, trust and respect (Ughamadu and Okoye 2006, ). Teaching is a calling/profession if one matches it with the characteristics of a profession. Since the schools cannot be stronger or better than their teachers who are the key agents in the implementation of the curriculum, then the teacher can be viewed as the hub of the educational system anywhere in the world. In the words of Ukeje (1979) "education unlocks the door to modernization and the teacher is the custodian of this key." An array of studies reveal that teachers who have similar professional qualifications (e.g. degree, certification, years of experience) instruct differently in their classroom and vary significantly in their ability to help students grow academically ( Rivkin, Hanushek, and Kain, 2005). Agwu (2001) defines teaching as a cluster of activities that the teachers engage in during some specific 
time period. Teaching is the different methods and the systematic means of presenting subject matter and learning experiences. According to Sequeirs (2012) it is an accepted fact that teachers are usually not born but made. Caupin, (2006) states that competency can be viewed in terms of "ability", "aptitude", "capability", “competence", "effectiveness", "knowledge and "skill". A competency is the capability of applying or using knowledge, skills, abilities, behaviors, and personal characteristics to successfully perform critical work tasks, specific functions, or operate in a given role or position. Kirschner and Thijssen (2005) describe the competency concept as a cluster of person-related qualities suitable to deal in a fitting manner with a clearly defined problem situation. It implies not only analytical and conceptual thinking, but also the development of meta-cognitive awareness, i.e. thinking and deciding in teaching; reflecting and adapting practices (Anderson, 2004; and Hay, 2000).

The major characteristics of the revised OTM curriculum include the incorporation of relevant information and communication technology (ICT) courses so as to allow the programme meet up with the technological trend according to the Federal Republic of Nigeria National Policy on Education (2004). Mmeremikwu-fiac and Onwukwe (2011) stated that business education teacher should be properly trained to acquire necessary and vital competencies needed at any point to be competent with what to be taught. For the sake of this study OTM courses are grouped into office application and office technology courses. Office Application courses according to NBTE (2004) are ICT and ICT related courses, Shorthand and Keyboarding related courses such as, Advance Shorthand Transcription, Desktop Publishing, Webpage Design, Database Management system, Keyboarding, Word Processing, ICT. According to Okoro (2011) competencies needed for teaching these courses include knowledge of keyboarding which include the right placement of fingers and having accurate speed in typing. Shorthand competencies include knowledge of the principles of writing shorthand, distinguished by writing half-length and double length strokes, dictating passages at the correct words per minute and reading back dictated passages. The teacher also needs to be competent in advance transcription such as transcribing dictated passages of varying speeds with a minimum of $95 \%$ accuracy. Business educators also need high speed when producing document using the computer, they need reprographic skill for producing the replica of a document, word processing skill, networking skill, computer excel package skill, spreadsheet manipulation skill, Microsoft word skill, operation of power point packages, internet service skills, video/teleconferencing skill, use of search engines, applying health and safety principles when working with the computer, database management skill, advanced desktop publishing skill, advanced web page design skill, information system and procedure skill, management information system skill, and professional career development that is competencies for job success and mobility.

Office technology competencies needed by business educators are ability to operate inter-office communication equipment such as intercom, telephone, e-mail, modern office technology, ability to teach records management, office practice, ability to use Xerox photocopier, projector, modern input devices such as scanners, digital camera, touch screens, use calculators, date stamping, sealing and addressing machines, demonstrate practical knowledge of machines in the model office, demonstrate knowledge of office procedure, operate shredding, franking and duplicating machines, operate telephone, tannoy system, e-fax and use of delivery trolley, facsimile reproduction. They also need competencies in the operation of desktop and laptop, palmtop, operation and use of tape recorder, operation of various types of printers, etc. Skill acquisition is sine quo non to an office technology and management student. They are expected to be proficient in the skills of operating different modern office technologies and to be knowledgeable in office procedure.

\section{METHOD}

Descriptive survey research design was adopted for the study. Anyakoha (2009), Osuala (2000), and Nworgu (2015) noted that when a survey centers on individuals and their opinions, beliefs, motivation, behaviour and when questionnaire is involved in collecting data the descriptive survey research method is the most appropriate. The area of the study is Adamawa, Bauchi and Taraba. The population for the study was 889 lecturers and students in the polytechnics offering OTM programme in the area of the study. The first group was made of up 49 lecturers while the second group comprised of 840 students. The total population of lecturers were 49 and all were used since it was a manageable size to handle. The Taro Yamane method of sampling was used to draw a sample size of 262 students out of 840 the population of students. Therefore, the total sample for this study was 311. The instrument for data collection was a 25-item structured questionnaire developed by the researchers. The instrument was titled "Business Educators Competency Level in Teaching Questionnaire" (BECLTQ). The questionnaire items were measured using 4-Point Rating Scale weighted as Very Competent (VC) 4points, Competent (C) 3 points, Moderately Competent (MC) 2 points, and Not Competent (NC) 1 point. The instrument was validated by two experts from the Department of OTM Federal Polytechnic Bali, and Bauchi respectively.

\section{Reliability of the Instrument}

In order to ascertain the reliability of the instrument a pilot study was conducted. 20 copies of the instrument was administered to lecturers and students in Federal Polytechnic Offa. The result obtained from the pilot study was subjected to the test of internal consistency using Cronbach Alpha procedure and it yielded a coefficient of 0.89 . This coefficient is high and positive, therefore, the instrument was adjudged reliable and suitable for this study. The questionnaires were administered by the researchers and research assistants. A total of 311 copies of questionnaires were produced and administered to the respondents. 301 were returned and out of this number 295 (98\%) questionnaires were properly filled and this was used for the analysis. 
World Journal of Innovative Research (WJIR)

ISSN: 2454-8236, Volume-6, Issue-2, February 2019 Pages 18-26

\section{Method of Data Analysis}

The data generated from the two research questions were analysed using Mean and Standard Deviation. The t- test was used to test the null hypotheses of no significant difference probability at 0.05 level of significance. Any item having a mean score of 2.50 and above was regarded as agreed while any mean score below 2.50 was regarded as disagreed. The decision rule for the hypotheses was that if the calculated t-value is equal or greater than the critical t-value, the hypothesis was rejected that is, there is a significant

Table I: Mean and standard deviation of responses on business educators' competency level in teaching office application courses difference. Similarly, if the calculated t-value is less than the critical t-value; the hypothesis was not rejected that is there is no significant difference.

\section{PRESENTATION AND ANALYSIS OF DATA}

\section{Research Questions}

Research Question one:What are business educators competency level in teaching office application segment of OTM courses in selected Polytechnics in Northeast Nigeria?

\begin{tabular}{lllllllll}
\hline S/N & Item Statements & & $\bar{X}$ & SD & Remark \\
\hline 1. & OTM business educators have the knowledge and skills in 3.12 & 0.97 & Competen
\end{tabular}

keyboarding so they are competent in teaching the course

2. They are competent in taking dictation at $120 \mathrm{wpm}$, dictate passages

$3.31 \quad 0.75 \quad$ Competent

fluently at the proper syllabic intensity and use the dictating machines

3. Demonstrate appropriate competence in teaching Advanced Desktop publishing, Webpage design etc.

4. Competent to type, copy, paste, delete, and save in Microsoft Word

$2.91 \quad 0.81 \quad$ Competent

5. Competency in selecting, developing, adapting, and using 3.44

0.69 Competent instructional strategies, material, and equipment

6. They are competent in using power point in preparing lessons and

0.96 Competent create new slides

7. OTM teachers demonstrates the knowledge of management information system, Records management, professional career development

8. They are competent in importing image, picture and sound to screen to make teaching more attractive

9. Creates Data on spreadsheets and database applications and uses excel 3.35

0.78 Competent packages effectively

10. Evaluates properly and uses drop box and grade centre to collect students work online

11 Creates, names and format files, folders and template

0.75 Competent

Competent in creating letters and email on-line and off-line, including

2.81

0.81 Competent the use of mail merge facility

13 Opening and working with more than one application at a time 2.84

0.87 Competent (multi-tasking)

14 Creating tables, charts, envelopes and labels

15 Accessing and displaying short-cuts and program icons on screen

1.82

1.12 Not Competent (CRT/VCD, LCD)

Weighted average

Analysis of data in Table 1 shows that the respondents indicated competent for all the item constructs except for item 7, 10 and 15. The respondents indicated that they are competent for item 1 to $6,8,9,11$ to 14 with mean ranges from 2.74 to 
Assessment of Business Educators Competency Level in Teaching Office Application And Office Technology Segments of Office Technology And Management Courses in Selected Polytechnics in North-East Nigeria

3.44. All 15 items in Table 1 have low standard deviation values which signifies low variability of responses. The table shows that the respondents unanimously indicated that they are competent for all the constructs as the mean is above the fixed mean of 2.50. This implied that business educators are very competent in teaching office application courses in Polytechnics in Northeast Nigeria. This was supported by mean and standard deviation of (mean $=2.86, \mathrm{SD}=0.88$ ).

Research Question II:What are business educators' competency level in teaching office technology segment of Office Technology and Management courses in selected Polytechnics in Northeast Nigeria?

Table II: Mean and standard deviation of responses on business educators' competency level in teaching office technology courses

\begin{tabular}{|c|c|c|c|c|}
\hline $\mathrm{S} / \mathrm{N}$ & Item Statements & $\overline{\mathrm{X}}$ & SD & Remark \\
\hline 1. & $\begin{array}{l}\text { OTM teachers have the competence to interconnect all computer } \\
\text { appliances and boot the computer }\end{array}$ & 3.30 & 0.90 & Competent \\
\hline 2. & $\begin{array}{l}\text { Business educators are competent in the use of Xerox photocopier, } \\
\text { projectors, and modern input devices such as scanners, Digital } \\
\text { cameras and touch-screens }\end{array}$ & 3.00 & 0.85 & Competent \\
\hline 3. & $\begin{array}{l}\text { They are competent in operating Desktop, Palmtop, Video machine, } \\
\text { Teleprinter and Handset as regards to teaching and learning }\end{array}$ & 3.01 & 0.90 & Competent \\
\hline 4. & $\begin{array}{l}\text { Business educators have the competence and ability to operate } \\
\text { inter-office communication equipment such as intercom, telephone, } \\
\text { e-mail etc. }\end{array}$ & 3.01 & 0.88 & Competent \\
\hline 5. & $\begin{array}{l}\text { They are competent in the use of calculator, date-stamping, sealing } \\
\text { and addressing machines, }\end{array}$ & 2.51 & 0.91 & Competent \\
\hline 6. & $\begin{array}{l}\text { Competent of the practical knowledge of the machines in the model } \\
\text { office }\end{array}$ & 3.05 & 0.78 & Competent \\
\hline 7. & They demonstrate competence and knowledge of office procedure & 3.19 & 0.85 & Competent \\
\hline 8. & $\begin{array}{l}\text { Competence of the operation of shredding, franking and duplicating } \\
\text { machines }\end{array}$ & 3.36 & 0.90 & Competent \\
\hline 9. & Operate telephone, tannoy system, E-fax & 2.90 & 0.89 & Competent \\
\hline \multirow[t]{2}{*}{10.} & Competent of the use of delivery trolley, and facsimile reproduction & 2.43 & 1.10 & Not Competent \\
\hline & Weighted average & 2.98 & 0.90 & Competent \\
\hline
\end{tabular}

Source: Field Survey, 2018

Analysis of data in Table 2 shows that the respondents $0.90)$. indicated that they competent for all the constructs except for item 10. The table showed that the respondents unanimously indicated competent for all the constructs as the mean is above the fixed mean of 2.50. All the 10 items has standard deviation ranging from 0.78 to 1.10 , which means the responses are clustered around their respective mean. This implied that business educators are very competent in teaching office technology courses in Polytechnics in Northeast Nigeria. This was supported by a mean score of 2.98 and a standard deviation of 0.90 (mean $=2.98, \mathrm{SD}=$

\section{TEST OF HYPOTHESES}

The two null hypotheses of the study were tested using independent t-test. The null hypotheses were tested at 0.05 level of significance.

$\mathrm{H}_{01}$ : There is no significant difference between the mean responses of lecturers and students on business educators' competency level in teaching office application segment of OTM courses in selected Polytechnics in Northeast Nigeria. 
Table III: Summary of t-test of the difference between the mean responses of lecturers and students on the business educators' competency level in teaching office application courses

\begin{tabular}{llllllll}
\hline Group & N & Mean & SD & t-cal & Df & p-value & Decision \\
\hline Lecturers & 49 & 2.94 & 0.16 & & & & \\
& & & & 2.023 & 293 & 0.044 & Rejected \\
Students & 246 & 2.85 & 0.29 & & & & \\
\hline \multicolumn{5}{c}{ Source: } & Field survey, 2018 & & P $<0.05$
\end{tabular}

Table 3 showed that there are 49 lecturers and 246 students. The lecturers had mean and standard deviation of 2.94 and 0.16 , respectively while students had mean and standard deviation of 2.85 and 0.29 , respectively. The calculated value of $\mathrm{t}$ was $2.023\left(\mathrm{t}_{293}=-2.023\right)$. The observed $\mathrm{p}$-value was 0.000 which is less than the fixed $\mathrm{p}$-value of $0.05 \quad(\mathrm{p}<0.05)$. Therefore, the null hypothesis was rejected. This means that there was significant difference between the mean responses of lecturers and students on the business educators'

Table IV: Summary of t-test of the difference between the mean responses of lecturers and students on the business educatorscompetency level in teaching office technology courses

\begin{tabular}{|c|c|c|c|c|c|c|c|}
\hline Group & $\mathbf{N}$ & Mean & SD & t-cal & Df & p-value & Decision \\
\hline \multirow[t]{2}{*}{ Lecturers } & 49 & 3.50 & 0.15 & & & & \\
\hline & & & & 6.028 & 293 & 0.000 & Rejected \\
\hline Students & 246 & 2.89 & 0.66 & & & & \\
\hline
\end{tabular}

Table 4 shows that there are 49 lecturers and 246 students who responded to the study. The lecturers had mean and standard deviation of 3.50 and 0.15 , respectively while students had mean and standard deviation of 2.89 and 0.66 , respectively. The calculated value of $t$ was 6.028 $\left(\mathrm{t}_{293}=-6.028\right)$. The observed $\mathrm{p}$-value was 0.000 which is less than the fixed $\mathrm{p}$-value of $0.05(\mathrm{p}<0.05)$. Therefore, the null hypothesis was rejected. This means that there was significant difference between the mean responses of lecturers and students on the business educators' competency level in teaching office technology courses in some selected Polytechnics in Northeast. This implied that lecturers and students differ significantly in their perception.

\section{DISCUSSION OF FINDINGS}

The findings of the study were discussed based on the answers to research questions and the hypotheses tested. The study in table 1 and 3 revealed that business educators possess competence in the teaching of office application segment of OTM courses in selected Polytechnics in Northeast Nigeria. The study discovered that business educators are competent in teaching keyboarding, dictate shorthand at $120 \mathrm{wpm}$, select, copy, paste, and save in Microsoft word and dictate passage fluently at the proper syllabic intensity. The findings also revealed that business educators have competency to select, develop, adapt and use instructional strategies, materials and equipment. Business educators use PowerPoint to prepare lessons and create new slides. The findings of this study was in agreement with the study of Okoro (2011) who reported that in teaching office application courses teachers need the knowledge of competency level in teaching office application courses in Polytechnics in Northeast Nigeria. This implied that lecturers and students differ significantly in their perception.

$\mathrm{H}_{02}$ : There is no significant difference between the mean responses of lecturers and students on the business educators' competency level in teaching office technology segment of OTM courses in selected Polytechnics in Northeast Nigeria.

keyboarding, dictation of passages at the correct words per minute and reading back dictated passages. Caupin (2006),Okereke (2008), Akarahu (2011), and Ekpenyong (2010) supported these statements when they said that competencies are important for building of skills and attitude and that information communication and technology knowledge is important in the $21^{\text {st }}$ century teaching also, business education prepares students with necessary competency for the world of work. The implication of this is that OTM students will be good in keyboarding, shorthand and they will be able to work on the Microsoft Word and Power point Packages. There was significant difference between the mean responses of lecturers and students on business educators' competency levels in teaching office application courses in selected polytechnics in Northeast Nigeria.

The findings in Table 2 and 4 showed that business educators have the competence to interconnect all computer appliances and boot the computer, operate inter-office communication equipment such as intercom, telephone and they also demonstrate competency in the use of calculator, date-stamping, scaling and addressing machines. Competency in teaching office technology are also found when both lecturers and students rated business educators to have practical knowledge of the machines in the model office. This corroborated with the studies of Nnaji (2014) when she found that business education is education for and about training in business skills, competency required for use in business offices, clerical occupations and that which gives occupational identity. NBTE (2004) agreed with the findings when they stated that OTM education is an aspect of business 
education designed to equip students with secretarial/office skills for employment in various fields of endeavour. This implies that students and graduates of OTM will be good in the use of these machines and they will also apply the knowledge of office procedure in performing their official task.

\section{CONCLUSION}

Based on the findings of the study, the following conclusions were drawn;

Competence is an important quality of a business educator. If the educators are effective and efficient in their business of teaching and learning the students as well as the graduates will be very useful after graduation. They will be able to work in the modern business office as employees or set up their own businesses and become employers of labour because they can use the different automations in the work place.

\section{RECOMMENDATIONS}

In view of the results of the study and the conclusions drawn, the following recommendations were proffered by the researchers:

1. Even though business educators are competent in teaching office application courses they should be eager to improve their competency level on those ICT packages where their competency level is low in order to be very competent in teaching those courses because this will also encourage the graduates to be self-reliant. This could be achieved through in-service training, attending conferences, seminars, workshops and symposiums where academic opinions will be shared for academic improvement.

2. Business educators should continue to maintain high level of competency in teaching OTM courses by going beyond traditional method of professional development. They should use current technologies and resources for continued professional development. They should also be eager to learn new skills by involving both formal and informal means of learning. As this will enable them develop additional knowledge in pedagogy and to acquire more knowledge about the advances made in the programme's curriculum.

3. Business educators should encourage students of OTM to be creative and innovative so that they will not be idle after graduation. They are trained for paid jobs and for self-reliance. The spirit of self-reliance should be inculcated into them by teaching them to make frequent use of the machines in the model office and computer laboratory because they are expected to use similar machines in their work place.

\section{ACKNOWLEDGMENT}

The researchers are highly indebted and grateful to the Tertiary Education Trust Fund (TETFUND) especially the executive secretary Dr. Abdullahi B. Baffa for accepting the proposal of this research work out of many and for sponsoring the entire research work. The researchers pray that God will sustain the organization so that they will continue to support and sponsor research works towards the improvement of the Nigerian educational system. The researchers' gratitude is also due to the Rector Federal Polytechnic Bali and his management team for their support and encouragement. The researchers are forever grateful to Dr. Frank Okoro for his patience, suggestions, kind corrections and professional support throughout the period of this research study. The researchers are also indebted to Mrs Sympathy Arikwandu, Dr. Joshua Mamman and Ali Mohammed for their assistance towards the completion of this study.

\section{REFERENCES}

[1] Ademiluyi, L.F. \&Okwuanaso, S. N. (2013). Influence of NBTE accreditation on the qualityof administrationand leadership of polytechnic office technology andmanagement programs. Association ofBusinessEducators of Nigeria Journal 1(2), 387-396.

[2] Akarahu, C.U. (2011). Competencies required by teachers of business education for effectiveteaching of entrepreneurship. Association of Business Education Journal 3(1), 192-205.

[3] Agwu, S.N. (2001). Teaching in Nigeria. Nigeria ISBN

[4] Anderson, L.W. (2004). Increasing teacher effectiveness. (2nd edition) Paris: UNESCO, IIEP

[5] Anioke, B.O (2014). Up-Dating of secondaryschools business studies curriculum contents andmethodologies towards coping with the new technology. Nigerian Journal of Business Education 1(3), 37-45.

[6] Anyakoha, E.U. (2009). Developing research skills: concepts and conceptual frame work.Nsukka: Great AP Express publishers Ltd.

[7] Asogwa, U.C., Uko, E.O., \&Omeh, B.U. (2011). Quality assurance of teachers for teaching oil palm production to students in senior secondary schools in Enugu State. Nigerian vocational association journal 15(1), 1-7.

[8] Ayelotan,O.J. \&Sholagbade, F.A. (2014). Infrastructural facilities and business education: office technology and management perspective: Association of Business Educators of Nigeria Conference Proceedings 88-97.

[9] Baba, E.I., Victor-igwe, J.N., \& Baba, D.D. (2015). Teachers' competencies improvement needs of business courses in polytechnics in Kogi State. Association ofBusiness Educators of Nigeria Journal 2(2), 322-333.

[10] Babat, L.A \&Madaki, E.D. (2011). Training and development of human resources throughbusiness education programmes, Journal of business educational research and development.

[11] Campbell, J. P., McCloy, R. A., Oppler, S. H., \& Sager, C. E. (1993). A theory of performance. In Schmitt, N. \&Borman, W. C. (Eds.), Personnel selection in organizations. San Francisco: Jossey-Bass.

[12] Caupin, (2006). ICB -IPMA Competence baseline, International Project Management Association. @ http:// onlinelibrary.wiley.com , ... 24 Issue

[13] Chigbuson, A.J (2014). Enhancing generic skills through business education for graduatesemployability in the $21^{\text {st }}$ century workplace. Nigerian Journal of Business Education 2(1), 425-434.

[14] Ehirheme, P.E (2014). Producing global workers through business education with office technology and management in perspective. Nigerian Journal of Business Education 2(1), 221-30.

[15] Ekpenyong, L.E. (2010). "Business education and entrepreneurship The missing link" An unpublished lead paper presented at the $22^{\text {nd }}$ annual national conference of association of business educators of Nigeria held at Federal college of education. Osele: Abeokuta on $12^{\text {th }}$ $-15^{\text {th }}$ October

[16] Elobuike, H.U. (2010). Qualities of a good teacher: A critical analysis for practicing andprospective teachers', LIT Academic Journal 1(1), 227-232.

[17] Enahoro, P.F.U. (2000) Promotion interview made easy. 100 questions and answers onEducation. An unpublished manuscript, Awka:

[18] Federal Republic of Nigeria (2004) National policy on education ( $^{\text {th }}$ Ed.), Lagos: NERDC

[19] Hay M.B (2000). Research into teacher effectiveness: A model of teacher effectiveness. Research report No. 216.Norwich: 
World Journal of Innovative Research (WJIR)

ISSN: 2454-8236, Volume-6, Issue-2, February 2019 Pages 18-26

[20] Hoffman T. (1999). The meaning of competency. Journal of European Industrial Training23(6), 25-286. Retrieved @ http:// www.iosrjournals.org

[21] Igberaharha, O.C. (2018). Assessing quality imperatives of business education programme among tertiary institution in Delta State. Nigerian Journal of Business Education, 5(2), 44-51.

[22] Kennedy, M. (1999). The role of pre-service teacher education. In Darling-Hammond, L. \&Sykes, G. (Eds.). Teaching as the learning profession: handbook of teaching and policy. San Francisco: Jossey-Bass.

[23] Kirschner, P. A. \&Thijssen, J. (2005). Competency development and employability. LL in E Long life learning in Europe, Vol. $X$ issue 2, pp. 70-75.

[24] Microsoft Encarta Dictionary @ Microsoft Corporation's 2009.

[25] Mmeremikwu-Fiac, C. \&Onwukwe, V. (2011). An assessment of business competenciesrequired of business education graduates for success in private enterprise. Association ofBusiness Education Journal 3(1), 182-191.

[26] National Board for Technical Education (2004).Curriculum and Course Specification for NDand HND Secretarial Studies. Kaduna:National Teachers Institute (2006). The role of tests in school based assessment. Manual for the re-training of primary school teachers. Kaduna: MDG project.

[27] Nnaji, F.O. (2014). Challenges of insecurity in Nigeria and the impact on business education: Association of Business Educators of Nigeria Conference Proceedings 133-139.

[28] Nnaji F.O. \&Ibe, E.O. (2014). Office technology and management for sustainable industrial development. Federal Polytechnic Mubi, Journal of Management and Technology 40-47.

[29] Njoku, C.U (2015). Critical incidence in the Nigerian educational system: challenges to business educators. Association of Business Educators Journal 2(2), 1-18.

[30] Nworgu, B.G. (2015). Educational research: Basic issues and methodology ( $3^{\text {rd }}$ edition).Nsukka: University Trust Publishers

[31] Obayi, A.U., Abuka, C.K., and Okeke A.U (2014). Preparing globally minded female students of Taraba State through business education. Nigerian Journal of Business Education 2(1), 410-424.

[32] Oborah, J.O. (2011). Basic ICT skills and keyboarding for office technology and management. Lagos: Adura Publishers.

[33] Okereke, W.C. (2008). Internet and marketing. Retrieved from www.com.bld.mll.com

[34] Okoli, B.E., Utoware, J.D., \&Kaizer, A.N. (2018). Quality assurance strategies for promoting skill acquisition in business education programme in Universities in South-East for sustainable national development in Nigeria. Nigerian Journal of Business Education, 5(2), 52-62.

[35] Okoro, F. (2011). Polytechnic teachers' perception of the relevance of components of office technology programme in meeting the ICT needs of contemporary office. Business Education Journal 7(1), 46-62.

[36] Okoye, A.C. \&Umezulike, A.N. (2014). Assessment of secondary school business studies teachers' effectiveness in using problem-solving and stimulation strategies. Association of Business Educators of Nigeria Journal 1(3), 64-71.

[37] Osuala, E.C. (2000). Introduction to research methodology. Onitsha: FEP. Publishers Limited.

[38] Ovbiagele, A.O. \&Mgbonyebi, D.C. (2018). Quality assurance and skill acquisition in Office Technologyand Management programme for national development. Nigerian Journal of Business Education, 5(2), 63-76.

[39] Pavlov, I.P. (1927). Conditioned reflex. London: Oxford University press.

[40] Rivkin, S. G., Hanushek, E. A., \&Kain, J. F. (2005). Teachers, schools, and academicachievement. National bureau of Economic research working paper 73(2), 417-458.

[41] Sequeirs . A.H. (2012) Introduction to concepts of teaching and learning. Retrieved @ http://kb.edu.hku.hk/index.php?id=84

[42] Shaibu, O.G., Oshiogwe, J.A., \&Mbaegbu, R.E.V. (2014). Business education curriculum and the information and communication technology. Association ofBusiness Educators Journal 2(1),231-240.

[43] Sheila, D. \& Simeon, D. (2015). Basic concept of assessment.Retrieved@ www.slideshare.net/jarry03/basic-concept-in-assessment.

[44] Skinner, B.F. (1989). The origins of cognitive thought. American Psychologist 44, 13-18.

[45] Taro Yamane (2015). Elementary sampling theory @ Page on ec.europa.eu.
[46] Ughamadu, K.A. \&Okoye, N.S. (2006). Principles, methods and strategies for effectiveTeaching. (2nd Ed.), Onitsha/Agbor: Lincel Publishers.

[47] Ukeje, (1979). Curriculum design and development. Kaduna: National Teachers Institute press Ltd. 